\title{
Introduction
}

\section{Austerity, Welfare and Social Citizenship}

\author{
Daniel Edmiston*, Ruth Patrick** and Kayleigh Garthwaite*** \\ *University of Oxford \\ E-mail: daniel.edmiston@sbs.ox.ac.uk \\ ** School of Law and Social Justice, University of Liverpool \\ E-mail: Ruth.Patrick@liverpool.ac.uk \\ ***Department of Geography, Durham University \\ E-mail: k.a.garthwaite@durham.ac.uk
}

Since the global financial crisis in 2008, an 'austerity consensus' has emerged across many advanced capitalist economies (Farnsworth and Irving, 2012). Despite differing institutional settings, there has been a notable degree of convergence on fiscal consolidation (Farnsworth and Irving, 2012; Taylor-Gooby, 2012). Alongside this, political administrations have repeatedly claimed that welfare profligacy and dependency are key causes of public sector debt and economic stagnation. On this basis, political leaders have cultivated a policy mandate to re-configure working-age welfare and constrain public social expenditure in this domain. Taken together, these reforms represent a 'new, more constrained and qualitatively different deal for citizens' (Dwyer and Wright, 2014: 33). The central objective of this themed section is to explore the impact of these developments and their significance for the shifting character and operation of social citizenship in countries pursuing a similar strategy of 'welfare austerity' (MacLeavy, 2011: 360).

To do so, the articles in this themed section principally focus on the UK context, where the political crafting of austerity has become intimately linked to a welfare reform policy agenda centred on: 'ubiquitous conditionality'; increased means-testing; a narrowing of welfare entitlements, cuts to benefit levels and coverage for certain groups; reductions in local authority budgets; and increased localisation of discretionary payments and funds (Dwyer and Wright, 2014; Watts et al., 2014; Hastings et al., 2015; Jensen and Tyler, 2015). A growing body of evidence is emerging that quantifies and qualifies the recent impact of welfare reforms and residualisation in the UK. This themed section builds upon this research by critically examining the exclusionary effects of welfare austerity in the UK and what this reveals about the changing ideals and institutions of social citizenship, both as a top-down status and as a bottom-up practice.

The articles focus on the post-2010 period, during which time the UK ConservativeLiberal Democrat Coalition and the Majority Conservative Government have sought to reform welfare in order to end what they portray as an endemic problem of 'welfare dependency' and correct what they suggest are perverse incentives created by the benefits system to reward those who 'choose' benefits rather than engaging in paid work (cf. Osborne, 2010; Duncan Smith, 2014). Working-age social security has been problematised as undermining efforts to improve the life chances of 'at-risk' groups who purportedly lack the 'aspiration', 'capacity' and 'incentive' to address their problematic 
lifestyle choices (Cameron, 2016; The Centre for Social Justice, 2016). This embedding of 'anti-welfare commonsense' (Jensen and Tyler, 2015) has occurred alongside regressive changes to working-age social security as well as direct and indirect taxation. Reforms have tended to favour pensioners and those in the upper middle of the income distribution, whilst women, younger people and those at the bottom (and those close to the top) of the income distribution have been the biggest losers (De Agostini et al., 2015; De Henau and Reed, 2016).

To establish whether welfare austerity represents a continuation or departure from previous policy approaches, these developments need to be situated within a broader historical context of welfare reform and fiscal recalibration. Since the 1980s, activation measures have gradually extended the reach and intensity of welfare conditionality in public services and social security administration (Dwyer, 2010; Dwyer and Wright, 2014). Across OECD countries, differing logics underpin welfare-to-work policy: from a more 'enabling' approach towards social investment in human capital, to a more 'regulatory' and disciplinary function relying on the use of negative incentives and welfare disentitlements (Raffass, 2016). Over the last thirty-five years, like many other liberal welfare regimes, the UK has undergone a gradual re-orientation from a more enabling programme of employment assistance to a more punitive and controlling activation strategy. In addition, there has been a steady but significant shift in the profile of public social spending with the provision and generosity of social security becoming increasingly contingent on the socio-demographic, familial and employment status of benefit claimants (Hills et al., 2010). Particularly between 1997 and 2010, greater selectivity and targeting of resources to tackle child and pensioner poverty saw pensioners, lone parents and working families experience real-term increases in certain benefits, while working-age single people and childless couples saw the value of their benefits stagnate or fall (Hills, 2013).

Whilst some benefit claimant groups have fared better than others since 2010, more recent policy developments can be seen as a continuation of longer-term trends in welfare provision that have made the status and rights of social citizenship increasingly fractured and conditional. Alongside this, however, some have argued that the scale, pace and nature of more recent reforms represent a more 'fundamental restructuring' of the UK welfare state (Taylor-Gooby, 2012).

Against this backdrop, this themed section builds on a UK Social Policy Association Workshop organised in January 2015 for postgraduate and early career researchers to explore the empirical relations between welfare, austerity and citizenship, and the extent of continuity and change observable over time. Over twenty-five years ago, Conover et al. (1991: 801) claimed that a great deal of citizenship theorising is 'conducted in what is virtually an empirical void'. Since then, a burgeoning body of literature has emerged in this field. Whilst substantial progress has been made, Isin et al. (2013) suggest that more needs to be done both empirically and conceptually. They outline a research agenda for studies that capture (a) the socio-structural practices that structure citizenship, (b) how (non-) citizens experience the inclusive and exclusive tendencies of citizenship and (c) 'the everyday world of citizenship' (Desforges et al., 2005) (Isin et al., 2013: 57).

With this in mind, this themed section includes articles from a new generation of social policy and sociology scholars each of which contribute towards this research agenda by exploring how welfare austerity has engendered an increasingly differentiated praxis and experience of social citizenship in the UK and further afield. The articles 
draw upon studies that employ a diverse range of qualitative, longitudinal, comparative, ethnographic and quantitative methods. These studies examine: the role of discrimination in welfare sanctioning in the UK (Aaron Reeves and Rachel Loopstra); the politics and responsibilisation of food bank use (Kayleigh Garthwaite); the effects of welfare reform over time on different social security claimant groups (Ruth Patrick); hidden forms of conditionality through disability and benefit claiming in Scotland (Kainde Manji); the precarious experience of women at the welfare-penal nexus (Larissa Povey); and lived experiences of poor and rich citizenship in the UK and New Zealand (Daniel Edmiston).

The conceptual indeterminacy of social citizenship makes it particularly difficult to establish its relation to austerity and welfare reform. As the review article of this themed section argues, greater conceptual attention to the constitutive features of social citizenship can help clarify some of the claims made about welfare austerity and its bearing on the effectiveness, inalienability and universality of social rights and citizenship status. Traditionally, examination of the exclusionary capacity of social citizenship has tended to conceive of 'noncitizenship' as the deprivation or negation of citizenship (Tonkiss and Bloom, 2015). However, deriving an understanding of 'noncitizenship' from its dualistic counterpart can obfuscate the nature and origins of socio-political marginality. By and large, 'noncitizenship' tends to be conceived as a static condition whereby individuals lack the status and rights conferred through collective membership. However, citizenship and 'noncitizenship' should be understood as an 'instituted process' through which social rights, responsibilities and status are negotiated and constructed in relation to the state (Somers, 1993). By advancing a relational, practice-based understanding of 'noncitizenship', it is possible to identify how the institutions of social citizenship function to regulate, discipline and exclude certain individuals from its distributional and symbolic promise. In this respect, the articles in this themed section offer a critical and timely contribution that moves towards an explanatory account of the relationship between citizenship, inequality and welfare austerity.

Through analysis of a longitudinal cross-local authority dataset, Reeves and Loopstra demonstrate how exclusionary practices have become integrated into the administrative architecture of the social security system in the UK. Emerging evidence suggests that the elevated role of welfare conditionality and sanctioning has had highly damaging financial, material, emotional and health effects on those reliant on low-income social security (Watts et al., 2014; Dwyer and Bright, 2016). Reeves and Loopstra illustrate how recent welfare reforms and attendant benefit sanctions have disproportionately affected vulnerable groups, including disabled people, lone parents and ethnic minorities. In practice, welfare arrangements have rarely, if ever, safeguarded equality of status between citizens. However, these findings demonstrate how institutional practices bound up in the politics of welfare austerity have advanced the exclusion of certain groups, and served to increase, rather than moderate, material and status inequalities between citizen members. Similarly, Patrick and Manji present evidence to suggest that welfare austerity has led to a further degradation of social citizenship, undermining its integrative capacity. Drawing on a qualitative longitudinal study exploring lived experiences of out-of-work benefit claimants, Patrick shows how citizenship has increasingly come to operate as a form of social control, a subversion of its emancipatory potential. Manji draws on a qualitative study to explore how increasing welfare conditionality is undermining the right to realise full and equal citizenship amongst disability benefit claimants in Scotland. She shows how those subjected to such reforms experience stigmatised identities both as disabled 
people and as benefit claimants, with a number of participants describing experiences of discrimination, bullying and harassment in their daily lives.

These experiences demonstrate the increasingly differentiated forms of citizenship arising through welfare austerity. Several of the articles explore how individuals negotiate the inclusive and exclusive tendencies of citizenship within this incipient welfare settlement. Based on a comparative study of lived experiences of poor and rich citizenship in New Zealand and the UK, Edmiston provides an account of how an increasingly paternalistic approach to welfare provision is further undermining a common sense of citizen identity and belonging. In seeking to navigate successive rounds of residualisation, Edmiston demonstrates how those experiencing deprivation often assume a position of subservience in their efforts to receive positive treatment and recognition from welfare agencies and staff. Similar findings from Garthwaite's article are reported in an ethnographic study of food bank users and volunteers in the North West of England. Garthwaite shows how attempts to realise the role of an 'active citizen' in the context of the 'Big Society' intensify many of the feelings of shame and inadequacy that low income citizens internalise. Individuals felt that they were expected to display deference, restraint and frugality in their engagement with food banks, and this further undermined the right to 'a modicum of economic welfare and security' (Marshall, 1950) for those seeking emergency food aid provision. Povey's study of women at the nexus of the UK welfare and criminal justice system also highlights how vulnerable groups are compelled to navigate relationships with welfare agencies, made more complex by their competing roles as both assistential and controlling. For many of the participants interviewed in Edmiston, Garthwaite and Povey's research, increasing conditions and administrative discretion attached to social assistance were experienced as a controlling and degrading intervention, which left them feeling dehumanised, with their own societal contributions devalued and undermined. This was not only felt in their interactions with welfare institutions and agencies, but also permeated into their daily lives and experiences.

Beyond engagement with welfare institutions, Manji and Patrick also demonstrate the more covert ways in which austerity and welfare reform are impinging on citizenship status, and thus furthering citizenship exclusion. Patrick discusses the ways in which welfare conditionality impacts upon targeted individuals' citizenship status, noting a trend towards 'conditioning', where people seek to govern and manage their own behaviour(s) in order to meet the demands of contemporary citizenship. Manji argues that official and media discourses around benefit claiming led to self-surveillance being practiced by disability benefit claimants, resulting in a subtle form of 'hidden conditionality', causing individuals to adapt their behaviour according to idealised notions of responsible citizenship.

The articles included in this themed section also demonstrate that an equally potent, socio-cultural form of citizenship affects common norms surrounding citizenship status, rights and duties. These norms are negotiated and reproduced through the everyday engagements and experiences of citizens. The articles in this themed section demonstrate that the sites and spaces in which citizenship is constructed, negotiated and managed extend well beyond engagements with state institutions to the 'everyday world of citizenship' (Desforges et al., 2005). In doing so, these articles offer an insight into the processes by which citizens and subjects of the welfare state are actively involved in the (de-)legitimation of welfare reform and austerity. Many of the articles in this themed section demonstrate how individuals are engaged in diverse private and public struggles 
for their rights, recognition and belonging. These 'acts of citizenship' are apparent in the multiple, and often divergent, discourses of citizens (Isin, 2008; Edmiston and Humpage, 2016).

On the one hand, this manifests itself through an internalised logic of welfare reform whereby individuals engage in strategies to defend their own entitlement to social assistance by endorsing the terms upon which social citizenship is granted. For example, Garthwaite details how many of those affected by welfare reform subscribed to the dominant ideals underpinning active citizenship, and sought alternative 'active citizen' status through volunteering, domestic work or the management of everyday poverty. Similarly, Edmiston demonstrates how citizens are actively engaged in the reproduction of societal norms associated with autonomous citizenship: affluent individuals in New Zealand and the UK were found to defend their own citizenship status and entitlements based on their employment and earnings record. Patrick also presents evidence on the stigma associated with out-of-work benefit receipt and subsequent attempts by individuals to distance themselves from this stigmatising identity.

On the other hand, individuals sought to defend their status and rights as social citizens by critiquing the existing welfare settlement and their own positioning within it. Across a number of the studies, participants were found to actively critique welfare reforms and narratives of welfare dependency. For example, Povey highlights how many of the women interviewed for her study actively criticised increased welfare conditionality and engaged in procedural struggles to defend their welfare entitlements. Similarly, Manji points to a number of examples of participants problematizing their treatment by welfare agencies and the general public. Overall, the articles in this themed section demonstrate how individuals affected by welfare austerity are engaged in subtle and distinct acts of claims making that highlight their political subjectivity as welfare claimants (Edmiston and Humpage, 2016). These private and public struggles have the capacity to both endorse and contest the current ideals underpinning social citizenship and therefore warrant greater theoretical and empirical attention in social policy and citizenship studies.

To meaningfully moderate material and status hierarchies between citizen members, it is necessary to reconceptualise and re-imagine social citizenship from the perspective of those whom it currently excludes. In doing so, the terms, rights and duties of social citizenship can be redefined to account for the attitudes, experiences and capacities of those marginalised by the existing welfare landscape. In this vein, many have sought to re-insert the 'grass-roots' perspectives and experiences of those that are notably absent from welfare debates (e.g. Lister et al., 2003). This themed section contributes towards this effort by exploring how citizens negotiate the everyday struggles that characterise welfare reform, austerity and social citizenship. Crucially, the articles are grounded in the lived realities and perspectives of citizens themselves. This collection thus makes an empirical and conceptual contribution to our evolving understanding of the varied and multi-dimensional effects of welfare austerity and of its implications for social citizenship in the UK and further afield.

\section{Acknowledgments}

We would like to thank the editors of Social Policy and Society and all anonymous referees for their generosity and expertise in supporting the publication of the articles included in this themed section. 


\section{References}

Cameron, D. (2016) 'Prime Minister's speech on life changes', London, Islington, https://www.gov.uk/ government/speeches/prime-ministers-speech-on-life-chances.

Conover, P., Crewe, I. and Searing, D. (1991) 'The nature of citizenship in the United States and Great Britain: empirical comments on theoretical themes', Journal of Politics, 53, 3, 800-32.

De Agostini, P., Hills, J. and Sutherland, H. (2015) 'Were we really all in it together? The distributional effects of the 2010-2015 UK Coalition government's tax-benefit policy changes: an end-of-term update', EUROMOD Working Paper Series 13/15, University of Essex, ISER, Colchester.

De Henau, J. and Reed, H. (2016) '10 years of austerity: the income on low-income households and women', Poverty, 154, Summer, 6-9.

Desforges, L., Jones, R. and Woods, M. (2005) 'New geographies of citizenship', Citizenship Studies, 9, 5, 439-51.

Duncan Smith, I. (2014) 'Jobs and welfare reform: getting Britain working', Speech to Business for Britain at Pimlico Plumbers, 8 April, Department for Work and Pensions, London.

Dwyer, P. (2010) Understanding Social Citizenship, Themes and Perspectives for Policy and Practice, Bristol: Policy Press.

Dwyer, P. and Wright, S. (2014) 'Universal Credit, ubiquitous conditionality and its implications for social citizenship', Journal of Poverty and Social Justice, 22, 1, 27-35.

Dwyer, P. and Bright, J. (2016) 'First wave findings: overview', Welfare Conditionality: Sanctions, Support and Behaviour Change, York: University of York.

Edmiston, D. and Humpage, L. (2016) 'Resistance or resignation to welfare reform? The activist politics for and against social citizenship', Policy and Politics, doi.org/10.1332/030557316X14802575969590

Farnsworth, K. and Irving, Z. (2012) 'Varieties of crisis, varieties of austerity: social policy in challenging times', Journal of Poverty and Social Justice, 20, 2, 133-47.

Hastings, A., Bailey, N., Gannon, M., Besemer, K. and Bramley, G. (2015) 'Coping with the cuts? The management of the worst financial settlement in living memory', Local Government Studies, 41, 4, $601-21$.

Hills, J., Brewer, M., Jenkins, S. P., Lister, R., Lupton, R., Machin, S., Mills, C., Modood, T., Rees, T. and Riddell, S. (2010) 'An anatomy of economic inequality in the UK', Report of the National Equality Panel, Government Equalities Office, London.

Hills, J. (2013) 'Labour's record on cash transfers, poverty, inequality and the lifecycle 1997-2010', Social Policy in a Cold Climate Working Paper 5, London: Centre for Analysis of Social Exclusion, London School of Economics.

Isin, E. (2008) 'Theorising acts of citizenship', in E. F. Isin and G. M. Nielsen (eds.), Acts of Citizenship, London: Zed Books, 15-43.

Isin, E. F., Nyers, P. and Turner, B. S. (2013) Citizenship between Past and Future, London: Routledge.

Jensen, T. and Tyler, I. (2015) "Benefits broods": the cultural and political crafting of anti-welfare commonsense', Critical Social Policy, 35, 470-91.

Lister, R., Smith, N., Middleton, S. and Cox, L. (2003) 'Young people talk about citizenship: empirical perspectives on theoretical and political debates', Citizenship Studies, 7, 2, 235-53.

MacLeavy, J. (2011) 'A "new politics" of austerity, workfare and gender? The UK coalition government's welfare reform proposals', Cambridge Journal of Regions, Economy and Society, 4, 3, 355-67.

Marshall, T. H. (1950) Citizenship and Social Class, Cambridge: Cambridge University Press.

Osborne, G. (2010) 'Our tough but fair approach to welfare', Chancellor's Speech to the Conservative Party Conference, 4 October, London.

Raffass, T. (2016) 'Work enforcement in liberal democracies', Journal of Social Policy, 45, 3, 41734.

Somers, M.R. (1993) 'Citizenship and the place of the public sphere: law, community, and political culture in the transition to democracy', American Sociological Review, 58, 5, 587-620 
Taylor-Gooby, P. (2012) 'Root and branch restructing to achieve major cuts: the policy programme of the 2010 UK Coalition Government', Social Policy and Administration, 46, 1, 61-82.

The Centre for Social Justice (2016) Improving Life Chances, London: The Centre for Social Justice.

Tonkiss, K. and Bloom, T. (2015) 'Theorising noncitizenship: concepts, debates and challenges', Citizenship Studies, 19, 8, 837-52.

Watts, B., Fitzpatrick, S., Bramley, G. and Watkins, D. (2014) Welfare Sanctions and Conditionality in the $U K$, York: Joseph Rowntree Foundation. 